CATALAN REVIEW

Catalan Review

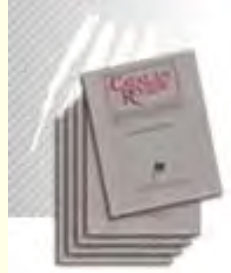

You are accessing the Digital Archive of the Catalan Review Journal.

By accessing and/or using this Digital Archive, you accept and agree to abide by the Terms and Conditions of Use available at http://www.nacs-

catalanstudies.org/catalan_review.html

Catalan Review is the premier international scholarly journal devoted to all aspects of Catalan culture. By Catalan culture is understood all manifestations of intellectual and artistic life produced in the Catalan language or in the geographical areas where Catalan is spoken. Catalan Review has been in publication since 1986 .
NORTH

AMERICAN

CATALAN

SOCIETY
Esteu accedint a l'Arxiu Digital del Catalan Review

A l' accedir i / o utilitzar aquest Arxiu Digital, vostè accepta i es compromet a complir els termes i condicions d'ús disponibles a http://www.nacs-

catalanstudies.org/catalan_review.html

Catalan Review és la primera revista internacional dedicada a tots els aspectes de la cultura catalana. Per la cultura catalana s'entén totes les manifestacions de la vida intel lectual i artística produïda en llengua catalana o en les zones geogràfiques on es parla català. Catalan Review es publica des de 1986.

\title{
Ramon Llull and the Dominicans Anthony Bonner
}

Catalan Review, Vol. IV, number 1-2 (1990), p. 377-392 


\title{
RAMON LLULL AND THE DOMINICANS
}

\author{
ANTHONY BONNER
}

A considerable amount has been written on Llull's relation with the Franciscans, ${ }^{\mathrm{I}}$ but singularly little on that with the Dominicans. ${ }^{2}$ This is partly, one imagines, because the first was positive and the second to a large extent negative, but it has always seemed to me that this second negative relation had effects on Llull's missionary program, on his apologetic method, and on his subsequent reputation, that in some cases were more far-reaching than his spiritual, intellectual and political dependence on the Franciscans.

In order to understand his relation with the Dominicans, one must know a bit about the situation of that order within the Crown of Aragon, a situation which was to have a decisive

${ }^{x}$ The principal study is that of Antoni Oliver, «El Beato Ramón Llull en sus relaciones con la Escuela Franciscana de los siglos xiII-xIv" , Estudios Lulianos (=EL) 9 (1965), pp. 55-70, 145-165; 10 (1066), pp. 47-55; 11 (1967), pp. $89-119 ; I_{3}$ (1969), Pp. 5I-65. Other studies on the subject are Francesc Sureda Blanes, "Franciscanisme i lul-lisme», La Nostra Terra 8 (1935), 243-260; the same author, «Franciscanismo y lulismon, Revista Eclesiästica ro(Madrid, 1936), 467-472, and II, pp. 26-36; Armand Llinarès, «L'actualité de Raymond Lulle, sa vie et ses attaches avec le franciscanisme», EL s (196I), pp. 199-200; J. N. Hillgarth, Ramon Llull and Lullism in Fourteenth-Century France (Oxford, 1971), pp. 52 ff. (particularly good); Jordi Gayà, “"Ars Patris Filius". Buenaventura y Ramon Llull», EL 27 (1987), pp. 21-36; and Miguel Cruz Hernández, El pensamiento de Ramon Llull (Madrid, 1977), pp. 59 ff. See also n. 5 below.

${ }^{2}$ The only study that treats the question at any length is that of Juan Tusquets, «Relación de Ramón Llull con San Ramón de Penyafort y con la orden de Santo Domingow, Escritos del Vedat 7 (1977), 177-195. For Penyafort and Llull, see Miquel Batllori, "Ramon de Penyafort i Ramon Llull» in A través de la història i la cultura (Montserrat, 1979), p. 58, and my "L'aprenentatge intel-lectual de Ramon Llull» in Studia in bonorem prof. M. de Riquer II (Barcelona, Quaderns Crema, 1987). For the problem of the Dominican chapter attended by Llull, see n. 39 below. 
effect on the beginnings of Llull's career. The driving force behind this order and its missionary activities in Aragon was Saint Ramon de Penyafort (II 85-I275). He had been confessor to Pope Gregory IX for whom he wrote one of the basic works of canon law, the Decretals promulgated in 1234 and still in vigor at the beginning of our century ${ }^{3} \mathrm{He}$ was master general of the order from 1238 to 1240 , and he later became one of the principal advisors to King James the Conqueror. From about 1245 , this man of enormous prestige and influence was active in trying to foment Dominican missionary activities in the crown of Aragon. And since these activities are so important for an understanding of Llull, I will give them in outline form:

1232 Prior to Penyafort's leadership in the field, there seems to have already been functioning in Majorca a school of Arabic for possible Dominican missionaries, under the aegis of a converso, Miquel de Bennassar, son of an Arab leader defeated just two years before. ${ }^{4}$

I 250 There was already functioning in Palma a Studium of some importance (whether new or a descendent of the previous one is unknown) to which were sent eight friars, among them the young Ramon Martí.

1 256-7 Ramon Martí writes his Explanation of the Creed.

I259 The Majorcan Studium, which seems to have continued functioning till 1256 , is now defunct, or at least seriously malfunctioning. the Koran.

1260 Ramon Martí writes his Summa against the Erros of

${ }^{3}$ Later he wrote an almost equally important Summa jus canonici.

${ }^{4}$ For evidence of this early school, as well as for other details of early Dominican missionary activities which correct the information presente in my Selected Works of Ramon Llull (1232-1316), 2 vols. (Princeton, N.J., 1985), pp. 95-6, see my «L'aprenentatge intel-lectual de Ramon Llull», Studia in bonorem prof. M. de Riquer II (Barcelona, Quaderns Crema, 1987), pp. I2-Is. 
I263 The famous disputation of Barcelona between Rabbi Moses ben Nahman and the Dominican Fray Pau Cristià takes place in the presence of James the Conqueror and Ramon de Penyafort. A year later Penyafort and Martí are members of the commission formed to supervise the implementation of restrictive measures adopted in the wake of the disputation.

I267 Ramon Martí writes his Capistrum Judaeorum.

I268-9 Ramon Martí, in Tunis, is unsuccessful in his attemps to convert the sultan, al-Mustansir.

I270-2 Saint Thomas Aquinas, at the request of Ramon de Penyafort (a request transmitted by Ramon Martí, who had been a fellow student with Aquinas under Albert the Great), writes his Summa contra Gentiles.

I 278 Ramon Martí writes his greatest apologetic work, the Pugio Fidei adversus Mauros et Judaeos.

If we put this alongside relevant activities of Ramon Llull during the same years, we begin to see relations and contrasts.

I 263 The probable year of Llull's conversion, recounted in the Vida coetània with many significant Franciscan details. ${ }^{5}$ Considering the fame of the disputation of Barcelona and Llull's apologetic aims, it is almost impossible that he did not know about this event of the same year. ${ }^{6}$

ca. I 264 The Vida coètania recounts how, «Having carried out these pilgrimages (to Rocamadour and Santiago de Compostella), he prepared to set out for Paris, for the sake of learning grammar there and acquiring other knowledge required for his tasks. But he was dissuaded from making this trip by the arguments and advice of his relatives and friends and

s See the Oliver study cited in n. I, EL 10 (1966), 47-55, and Jordi Gayà, " "De conversione sua ad poenitentiam": reflexiones ante la edición crítica de "Vita coetanea"", EL 24 (1980), pp. 87-91.

${ }^{6}$ As Robert D. F. Pring-Mill suggested in his «Grundzüge von Lulls Ars inveniendi veritatem", Archiv für Geschichte der Philosophie 43 (196r), p. 242, and his El microcosmos lul lià (Palma, 1961), pp. 22-3. 
most of all by Brother Ramon [de Penyafort] of the Dominicans, who had formerly compiled the Decretals for Pope Gregori IX, and those counsels made him return to his own city, that is, to Majorca»?

ca. 1265 Llull buys a Moslem slave in order to learn Arabic, a slave who apparently stays with him for nine years.

I 274-s A Franciscan theologian from Montpellier examines Llull's Book of Contemplation on behalf of the King of Aragon and finds it "full of prophecy and Catholic devotion». ${ }^{8}$ 1276 The school of Miramar is founded, so that, as the Vida coetània says: «thirteen Franciscan friars be sent there to learn Arabic for the purpose of converting unbelievers».

As to Ramon de Penyafort's advice in Barcelona, there has always seemed to be a slight note of bitterness in the way Llull recounts it, stating how he was already "prepared to set out for Paris» when «he was dissuaded» from doing so. ${ }^{9}$ But more than that, one must ask why the aging Dominican gave him such advice. Hillgarth's surmise is surely right: "Mallorca could give him something unavailable at Paris, a thorough training in Arabic, together with an intimate knowledge of Islam as a living faith", two things which combined would give "him a unique advantage over almost all the great scholastics who were his contemporaries, Albert the Great, Tho-

7 See my Selected Works mentioned in n. 4 above, p. 17.

${ }^{8}$ Ibid. p. 24.

${ }^{9}$ It is, I believe, the only time Llull expresses a contraried wish in the Vita coetania. Moreover, we must remember that the passage of that work quoted here was dictated in Paris in $\mathrm{r}_{3} \mathrm{II}$, and that this intellectual capital of Europe, which he had to conquer to make his teachings acceptable, had been a thorn in his side until this last trip when he dictated the Vita. He may have felt that had he received an adequate scholastic training, he would not have been the intellectual odd-man-out he had been on his three previous trips, and he would have been better prepared for the struggles he had had to face in persuading - above all the University people - of the rightness of his Art as an apologetic method. 
mas Aquinas, Bonaventure, Dunst Scotus" ${ }^{10}$ But one mustn't rule out the additional possibility that in the Majorca of 1264 there still existed some remnants of the former missionary school - some teacher, some already formed student, some library - where Penyafort thought Llull could study. It is also possible that the aging Dominican - he was at this point almost eighty -, tired and dissappointed by the lack of success of his studia arabica, dreamed that a younger figure with the fervor of Llull would be able to revive the Majorcan studium. None of these three possibilities are mutually exclusive, and they might all - to a lesser or greater degree - have been present in Penyafort's mind when he gave Llull his advice.

But more important is how Llull recounts his subsequent nine years of study in Majorca. Most of it has to do with the Muslim slave he bought in order to learn Arabic (were there no Dominican teachers, libaries, etc. where he could have studied?) Given the coincidence of missionizing and apologetic roles, it is astonishing that there is not a single mention of any positive relations with the Dominicans during his years of intellectual apprenticeship. Evidence for negative relations, however, are not lacking, and were to continue for the rest of his life.

In the first place there was the problem of Dominican apologetic methods. As Robert Chazan (as well as Eusebi Colomer) have recently, ${ }^{\text {II }}$ shown these involved trying to un-

${ }^{10} \mathrm{~J}$. N. Hillgarth, Ramon Llull and Lullism in Fourteenth-Century France (Oxford, 1971), p. 6.

"Robert Chazan, «From Friar Paul to Friar Raymond: the Development of Innovative Missionizing Argumentation ", Harvard Theological Review 76, 3 (1983), pp. 289-306, incorporated into his later Daggers of Faith. Thirteenth-Century Christian Missionizing and Jewish Response (Berkeley/Los Angeles, University of California Press, 1989). Eusebi Colomer, «El pensament de Ramon Llull i els seus precedents històrics com a expressió medieval de la relació fe-cultura", Fe i cultura en Ramon Llull, «Publicacions del Centre d'Estudis Teològics 
dermine the underpinnings of the adversary's faith by acquiring a knowledge of and attacking directly the authoritates on which this faith was based. Furthermore, and this is important to realize with the Dominicans and Llull's reaction to their methods, their apologetics became increasingly - and one might even say obsessively - directed against the Jews. The result was to base arguments not only on the Old Testament, but mainly on the enormous mass of intervening Rabbinic literature. This technique was initiated by Fray Pau Cristià in the Barcelona Disputation of 1263 , and subsequently refined by Ramon Martí, to the point that Chazan can say of the Pugio Fidei that it is

in many ways the magnum opus of medieval Christian missionizing among the Jews. No work can match the Pugio Fidei for its dedicated effort to probe the Jewish psyche, for its massive collection of Jewish sources, for its careful and sophisticated argumentation on the broadest possible range of theological issues. ${ }^{12}$

But at the same time Chazan suggest that this enormous effort at refinement might have been spurred by certain dissatisfaction with the results of the Disputation of 1263 , whose lack of complete success could have been attributed to the rather amateurish use made by Friar Pau Cristià of his innovative methods. ${ }^{13}$

Llull, however, attributed their lack of success to another source. Already in the Doctrina pueril (1274-6) he says «ne rahons fundades sobre actoritatz no reeben les infeels", ${ }^{14}$ and in the Disputació de cinc savis (1294) he expands on the theme:

de Mallorca» II (Mallorca, 1986), pp، 9-29, and Eusebi Colomer, «Ramón Llull y Ramón Martín, EL 28 (1988), pp. I-37.

${ }^{12}$ Chazan, Daggers of Faith, p. IIs.

${ }^{13}$ Loc. cit.

${ }^{14}$ Ed. Gret Schib, Els Nostres Clàssics, Vol. 104, p. 197. 
no curam tractar en aquest tractat d'auctoritats, com sia assò que auctoritats pusca hom espondre en diveres maneres e aver d'eles diverses oppinions, per les quals se multipliquen paraules e esdevé l'entenimén en confusió, adoncs com los uns hòmens disputen ab los altres per auctoritats. ${ }^{\text {IS }}$

But it is in the Proverbis de Ramon (1296 ?) that Llull puts it in most lapidary fashion: «Disputar per autoritats no ha repòs». ${ }^{16}$ Another opposition to Dominican methods is implicit rather than explicit in Llull's works. The Dominicans, as we have seen, began to concentrate more and more on the Jews. This is not the place to go into the social and psychological reasons for this emphasis, ${ }^{17}$ but only to state that Llull quite rightly saw the problem in a much more general politico-religious context, in which Islam was a world power capable of threatening Christianity on many fronts, ${ }^{18}$ and in wich the Jews were little more than a problematical minority.

But more important, and with more far-reaching consequences for Llull, was another opposition to Dominican methods. In seven places in his works - the figure is significant in a person like Llull given more to examples than obsessions -

is Ed. Josep Perarnau, Arxiu de Textos Catalans Antics s (1986), p. 34 . In the Book of the Gentile and the Three Wise Men Llull puts a similar complaint in the mouth ofthe Jew: "We and the Christians agree on the text of the Law (= the Old Testament), but we disagree in interpretation and commentaries, where we reach contrary conclusions. Therefore, we cannot reach agreement based on authorities and must seek necessary arguments by which we can agree. The Saracens agree with us partly over the text, and partly not; this is why they say we have changed the text of the Law, and we say they use a text contrary to ours". See my Selected Works, 170.

${ }^{16}$ Obres de Ramon Llull, Vol. XIV (1928), p. 271.

17 As I have suggested in an article to appear shortly, this partook of the traditional prejudices concerning the Jew as the internal enemy, as the outsider within an otherwise homogeneous society. Colomer also brings out the elements of verbal violence in Ramon Marti's otherwise so admirably researched Pugio Fidei; see his «Ramón Llull y Ramón Martí», EL 28 (1988), p. 18.

${ }^{18}$ Including that of the Holy Land, the last Christian bastion of which - Acre - had succumbed in 1291 . 
he tells the story of a monk persuading the sultan of Tunis of the falsity of Islam, but then when the sultan asks him to prove the truth of Christianity, only being able to answer it was a matter of faith, undemostrable by necessary reasons. The sultan, angry at having been persuaded to abandon his own faith without being able to replace it with a new one, ${ }^{19}$ issues dire threats to the monk and has him expelled from his Kingdom. ${ }^{20}$ Longpré years ago identified the monk as Ramon Martí and the sultan as al-Mustansir, and placed the event during the former's stay in Tunis during $1268-9,{ }^{21}$ so it is difficult to see this story as anything but a strong counterexample directed against Dominican methods.

And the reasons it had such strong, largely negative, consequences for Llull, had to do with the fact that Dominican policy on this question became for multiple reasons official Church dogma. This dogma stated that there were certain things that we know only through revelation and are unprovable by rational means - things such as the Trinity, the Incarnation, the creation of the world, etc. ${ }^{22}$ Llull, however, said that if we don't find some way to prove the Trinity and the Incarnation, Muslims and Jews will never listen to us. ${ }^{23}$ These are not only the principle differentiating dogmas of

19 The sultan's answer on this score became a kind of maxim for Llull, one that appears over and over again in his works: «Nolo dimittere credere pro credere, sed bene credere pro intelligere».

20 The various places in which the story appears are listed in my Selected Works, p. 96, n. 21 .

${ }^{2 x}$ Ephrem Longpré, "Le B. Raymond Lulle et Raymond Martí, O.P.", $B S A L 24$ (1933), pp. 269-271, reprinted in $E L_{13}$ (1969), pp. 197-200. For a curious colophon to this story, see EL 29 (1989), 87-8.

${ }^{22}$ Llull was well aware of the case for the opposition when he said: «Non est bonum quod fides et Articuli fidei posint probari, quia, ut scriptum est, perderetur meritum fidei; nam fides no habet meritum ubi humana ration praebet experimentum». Disputatio Fidei et Intellectus, Raymundi Lulli Opera omnia, ed. Ivo Salzinger, Vol. IV (Mainz, 1729), $480=$ viii, L.

${ }^{23}$ See my Selected Works, p. 193, n. 8. 
Christianity, but they are the ones that Muslims and Jews find most unacceptable, even from the point of view of ordinary reason. This, of course, is why Llull invented a system so abstract as his Art, one which, starting from premisses generally acceptable to everyone, could then build a structure capable of proving the Trinity and Incarnation. Or to put it another way, Llull, starting from a set of axioms which dealt in a most general way with the attributes of God, wanted to prove the Articles of Faith; the Dominicans considered the Articles of Faith the only possible axioms of any theological structure, and the attempt to prove them heterodox, if not heretical. ${ }^{24}$

In the 1280 's Llull criticized the Dominicans, this time rather directly, in his two novels Blaquerna and Fèlix. He accuses them, for instance, of being too legalistic (or «decretalistic») in their training at Bologna, and as a result being too worldly in their outlook, as well as unable to counsel people in a properly human and spiritual way in the confessional. ${ }^{25}$ He contrasts the inefficacy of their preaching with the efficacy of the exemplary actions of the protagonists of Blaquerna, and he critizes a Dominican chapter for offering more prayers for dead brothers (who, wince they are in Heaven, scarecely

${ }^{24}$ In addition Llull proposed an apologetic method that was positive, in that it tried to prove the truth of Christian dogma; whereas the Dominican method was the traditional negative one of trying to prove the falsehood of the opponent's religious tenets. In this respect it is significant that in Tunis in 1293 , during his first trip to North Africa, Llull offered to debate with the local doctors of Islam, promising to convert to their religion if he found their arguments more valid, only insisting that he be allowed to argue the foundations of the Christian faith on an equal footing. It was basically the tactical scheme of the Book of the Gentile; see my Selected Works, p. 34.

25 See Blaquerna, chap. 86, and Fèlix, chap. 103, cited in Tusquets (see n. 2 above), p. 191, and by Fernando Domínguez in Raimundi Lulli Opera Latina $(=R O L)$ Vol XV (Turnhout, 1987), xxxix-xli. The reference to the Decretals harbors it seems to me, an implied criticism of Ramon de Penyafort, or at least of his followers. 
need them) than for infidels doomed to die in ignorance of Christian truths. ${ }^{26}$

If we contrast this with the Franciscan elements that appear in the chronological outline of Llull's activities printed above (the Franciscan details of his conversion, ${ }^{27}$ the Franciscan monk who approves the Book of Contemplation, and Miramar being founded to train thirteen Franciscan Friars, $)^{28}$ we can see that up to this point in his career almost all his remarks and actions that have to do with the Dominicans are critical, complaining or run counter to their stated policies; whereas with the Franciscans everything is sunny and positive.

And it is important to remember that this preference was taking place amid a growing rivalry and state of friction between the two Mendicant Orders. In the south of France, Llull's principal place of residence during these years, the struggles between them reached alarming levels of verbal and sometimes physical violence. ${ }^{29}$ They quarrelled over control of the Inquisition, over the problem of the Vaudois, over building sites for convents, and above all over the problem of the Franciscan Spirituals (of wich more in a moment). ${ }^{30}$ And they were not totally adverse to trying a bit of demagogy to incense crowds against the adversary.

Also noteworthy when considering Llull's position was the opposed attitudes of the two orders to the famous decree of 1277 of the Bishop of Paris, Étienne Tempier, condemning

${ }^{26}$ Blaquerna, chaps. 18 and 90. Cf. Tusquets and Dominguez, loc. cit.

27 See n. 5 above.

${ }^{28}$ Precisely in the crown of Aragon where, as we said before, the Dominicans were the acknowledged leaders in the field.

${ }^{29}$ See Yves Dossat, «Les origines de la querelle entre Prêcheurs et Mineurs provençaux. Bernard Délicieux» in Franciscains d'Oc. Les Spirituels ca. 1280-1324. Cahiers de Fanjeaux 10, pp. 315-354.

$3^{30}$ Here the problem was more complicated, because the Friars Minor were themselves divided and of changing minds over the problem. 
219 doctrines of the "radical Aristotlians» and «Averroists» of the Arts Faculty. Hillgarth says:

Strong opposition to the decree of $\mathrm{r} 277$ came not only from the Arts Faculty but from the Domincans, who had adopted Aquina's synthesis as the official philosophy of their Order. This opposition aroused defenders of the decree, especially among the Franciscans, who considered themselves the heirs of Bonaventure's critique of extreme Aristotelianism. ${ }^{3 I}$

And into this fray Llull stepped to defend the Franciscan position in his Declaratio per modum dialogi of 1298 , where he justifies the condemnation article by article. ${ }^{32}$

Another factor that surely must have raised Dominican hackles was his relation with the Franciscan Spirituals. Like them, this self-proclaimed «procurador del infeels» had a certain taste for criticizing the establishemt, ${ }^{33}$ of wich the Dominicans were gradually becoming guardians. To be sure he never adopted the extreme apocalyptic or social views of the Spirituals, but nonetheless he was on good terms with people like Ramon Gaufredi, the last General of the order to defend the more extreme elements within the order, and who in 1290 gave Llull a recommendation to preach in the Franciscan monasteries of Italy, with Bernard Délicieux (of whom more in a minute), and with his famous Catalan contemporary, Arnau de Vilanova. ${ }^{34}$ That he knew the greatest theologican among the Spirituals, Jean-Pierre Olivi, who was lector at the Franciscan studium at Montpellier during the

${ }^{31}$ Hillgarth, op. cit., p. 250.

${ }^{32}$ Edited in Otto Keicher Raymundus Lullus und seine Stellung zur arabischen Philosophie. Mit einem Anhang, erhaltend die... «Declaratio...», «Beiträge zur Geschichte des Philosophie des Mittelalters VII (Münster i. W., 1909), and more recently in ROL XVII (1989). For Llull's debt to Bonaventure, see Gayà article cited in $\mathrm{I}$ above.

${ }^{33}$ See the introduction to Felix, or the Book of Wonders in my Selected Works, Vol. II, p. 652.

34 See Hillgarth, op. cit., 53-5. 
I290's, seems more than probable. ${ }^{35}$ That these people were grouped together in the mind of the establishment is revealed by the condemnation of Llull, Arnau de Vilanova and Olivi by the «leading curialist theologian", Augustinus Triumphus, towards the end of Llull's life. ${ }^{36}$ As for Bernard Délicieux, in his trial of I3I9 (some three years after Llull's death), one of the background factors introduced to support the accusation of his having poisoned Benedict XI was his having been found owning a copy of a book given to him by Llull in Rome in 1296 and containing the Taula general, the Tree of Science and other equally suspicious works. ${ }^{37}$

It was in 1293 , half way between receiving the letter of recommendation from Gaufredi and meeting with Bernard Délicieux in Rome, that Llull suffered his great spiritual and psychological crisis in Genoa. After his initial breakdown «he had himself carried or led to the church of the Dominicans» where, after his first bout of hallucinations, he «sent for the friars of the house and asked to be clothed at once in their habit; but the friars put off doing it because the prior was away». Then,

upon returning to his own lodgings, Ramon remembered that the Franciscans had accepted the Art which God had given him on the mountain much more willingly than the above-mentioned Dominicans. Whereupon, hoping that said Franciscans would promote the Art more efficaciously for the honor of our Lord Jesus Christ and for the good of the Church, he thought that he would leave the Dominicans and enter the Franciscan order.

Then, amid another bout of hallucinations, a voice emanating from a «light or pale star» on the ceiling said to him threateningly «Did I not tell you that you could only be saved in the Domini-

35 Hillgarth, loc. cit.

${ }^{36}$ See Hillgarth, op. cit., pp. 55-6, and $R O L \mathrm{~V}$, pp. I0I-3.

37 T. \& J. Carreras y Artau, Historia de la filosofia española. Filosofia cristiana de los siglos XIII al XV, 2 vols. (Madrid, 1939-43), Vol. II, p. I9. 
can Order? Be careful what you do!» This made him realize that «he would be damned unless he remained with the Dominicans, while on the other hand his Art and books would be lost unless he remained with the Franciscans». He therefore

chose (which was most admirable of him) his own eternal damnation rather than the loss of the Art which he knew he had received from God for the salvation of the many and especially for the honor of God himself. And thus, in spite of the disapproval of the aforementioned star, he sent for the Guardian of the Franciscans, whom he asked to give him their habit. The Guardian agreed to give it to him when he was nearer death..$^{38}$

Here, in spite of the atmosphere of acute psychological crisis in which events take place, the opposition between the two orders in their attitude towards Llull and his Art could scarcely be clearer, nor Llull's fears of Dominican condemnation more dramatic.

At the same time, this event shows us another aspect of the question. Surely the last thing Llull wanted was Dominican hostility. For a man trying to reunite all the forces of Christendom in the task of persuading Muslims and Jews of the truth of Christianity, the fact of the Preachers' condemnation of his Art, which he so strongly felt was God-given, must have been painful. The fact of his staying with them and even wanting to join their Order in Genoa, and that at other times he attended three of their general chapters, ${ }^{39}$ should be proof enough of his attempts to enlist their support, or at least to try to parry their emnity.

\section{${ }^{8}$ See my Selected Works, pp. 3 1-2.}

39 Along with three of the Franciscan order; cf. Desconhort, stanza 14. There has been a certain amount of bibliographical wrangling over which or the historical general chapters Llull attended; see Alòs-Moner's note in his edition of Ramon Llull, Poesies, Els Nostres Clàssics (=ENC), Vol. 3 (1928), p. I48; Miquel Batllori, "Certeses i dubtes en la biografia de Ramon Llull», $E L_{4}$ (1960), pp. 319-320; and Erhard-Wolfram Platzeck, «Miscelánea luliana. Investigaciones publicadas en los últimos veinte años sobre la vida y la interpretación de las 
But if this task was already difficult, it was only made worse by the doings of Llull's devotees after his death. In the 1330's a group of Valencian followers of the Spirituals of dubious orthodoxy started copying genuine and fabricating spurious Lullian works; by the 1360 's they had begun to attract the attention of the Dominican Inquisitor of Aragon, Nicolau Eimeric, and to a certain extent might have been the triggering factor in his later anti-Lullian campaign. ${ }^{4}$

But even though Llull might have, in the minds of more bien-pensant people, been slipping into the shadowy regions of people who kept the wrong company and propagated ideas of a strangely esoteric nature, even if he was beginning to take on the aura of the magus he was to become in the later sixteenth century, and even though some of these aspects of his reputation migh

doctrinas de Raimondo Llull», Verdad y Vida 31 (Madrid, 1973), pp. 403-4 and n. 17.

$4^{\circ} \mathrm{On}$ this Valencian Lullist group see the following studies: Josep Tarré, "Un quadrenni de producció lul lista a València (1335-1338)", Studia Monographica et Recensiones 6 (Palma, 195I), 22-30; Hillgarth, op. cit., PP. I48-9; three articles by Josep Perarnau: «Un manuscrit lul-lià no identificat. Vic, Museu Episcopal, 35", Analecta Sacra Tarraconensia 46 (1973), 76-8, 81-2; “Consideracions diacròniques entorn dels manuscrits lul-lians medievals de la "Bayerische Staatsbibliothek" de Munic", Arxiu de Textos Catalans Antics (= ATCA) 2, p. 133; and «El lul-lisme, de Mallorca a Castella a través de València. Edició de 1"'Art abreujada de confessió",", $A T C A_{4}$ (1985), pp. 6I-172; and finally, Jaume Puig i Oliver, "El procés del lul-listes valencians contra Nicolau Eimeric en el marc del Cisma d'Occidentn, Boletin de la Sociedad Castellonense de Cultura 56 (1890), 319-463. The extent to which Llull's image could be deformed by counter-cultural figures is perhaps best symbolized by the Franciscan Spiritual (and alchemist), John of Rupescissa (Rocatallada or Peratallada in Catalan), who in 1356 wondered if uthat bearded philosopher, as he is known in Paris, that is Raymond Luylh of Majorca, who, even though he is a layman and almost illiterate, arrived at the summit of philosophy", might not be,the new Minerva whom the oracle predicted would come to «reveal her science and secrets confirmed by Art». See Louis Boisset, «Un témoignage sur Lulle en 1356: Jean de Roquetaillade", in Raymond Lulle et le Pays d'Oc, Cabiers de Fanjeaux 22 (Tolosa, Privat, 1987), pp. 70-74. 
have, as we suggested, triggered Dominican opposition, this was never the center of their complaint about Llull. The anti-Lullist campaign wich began with Eimeric centered on doctrinal issues. He took issue with the attempt to prove the Articles of Faith and with the mechanisms Llull used to do this - the Dignities of God, the activity of the dignities and the corresponding correlative mechanism, etc., - all of which, for Eimeric, added up to the sin of rationalism. This was at the heart of the one hundred "Raimundi Lulli errores" published in his Directorium inquisitorum of $\mathrm{I} 376,{ }^{4 \mathrm{I}}$ a highly influential work, which not only provided the arguments for the papal bull of the same year censuring Llull and condemning twenty of his books, ${ }^{42}$ but was also printed in Barcelona in 1503 , and then reprinted in Rome and Venice five times between 1578 and 1607 .

This Dominican "campaign» against Llull however, should not be seen as a new current set in motion by the obsessions of a single figure, ${ }^{43}$ no matter how influential he was, but rather as the end result of an opposition to Llull's doctrines and methods which dated from the very beginning of the Majorcan's career. Eimeric might have given the condemnation an impetus and consistency it would not otherwise have had; but aside from that, all he did was articulate a sentiment which must have been general within his Order for almost exactly a century when he presented his manual for inquisitors in Avignon in January of 1376 . And this ongoing opposition must have done considerable harm to Llull's plans for the propagation of his missionary and apologetic methods, which, as we pointed out before, would explain his

${ }^{4}$ For this and other works of Eimeric, see Alois Madre, Die theologische Polemik gegen Raimundus Lullus: eine Untersuchung zu den Elenchi auctorum de Raimundo male sentientium (Münster, 1973), pp. 71-9, and pp. 147-1 59 for the hundred errors.

$4^{2}$ See my Selected Works, p. 72 for the relevant bibliography.

43 Which is not to say that Eimeric was not obsessed with Llull. To write as much as he did against a single person, and to occupy so much of a general manual for Inquisitors inveighing against that same person, is surely obsessional. 
attempts to parry so obvious and serious a danger. It would also have (along with the Parisian Theology Faculty's condemnation of $1390,{ }^{44}$ and with his growing status as a magus and alchemist $)^{45}$ strongly contributed to the underground nature of Lullism prior to the French movement lead by Jacques Lefèvre d'Étaples and Charles de Bovelles at the end of the fifteenth and beginning of the sixteenth century. An it would constitute a kind of albatross around the neck of Llull's reputation for centuries to come, provoking for example the violent outbursts in eighteenth-century Majorca, ${ }^{46}$ and draping him with a veil of suspicion that was not to be removed until modern studies began to be able to see things in historical perspective.

ANTHONY BONNER MAIORICENSIS SCHOLA LULLISTICA

44 Instigated by Jean Gerson; see my Selected Works, p. 72.

45 For the growth of the pseudo-Lullian alchemical tradition, see the recent (and first serious) survey of the question in Michela Pereira's The Alchemical Corpus Attributed to Raymond Lull, "Warburg Institute Surveys and Texts» 18 (Londres, 1989).

${ }^{46}$ See, for example, the campaigns of the Dominican Martín Serra and of the bishop Juan Diaz de la Guerra outlined in Lorenzo Pérez Martínez, «Datos sobre el antilulismo del dominico Fray Martín Serra ( † I715)», Homenaje a D. Jesús Garcia Pastor, Bibliotecario (Palma: Conselleria d'Educació i Cultura del Govern Balear, 1986), pp. 62-77, and Juan Rosselló Lliteras, «Don Juan Díaz de la Guerran, $E L 28$ (I988), pp. 51-70, 21 I -241 . 